\title{
Diversity of Aerobic Methanotrophic Bacteria in a Permafrost Active Layer Soil of the Lena Delta, Siberia
}

\author{
Susanne Liebner • Katja Rublack • \\ Torben Stuehrmann • Dirk Wagner
}

Received: 15 November 2007 / Accepted: 20 May 2008 /Published online: 1 July 2008

(C) The Author(s) 2008

\begin{abstract}
With this study, we present first data on the diversity of aerobic methanotrophic bacteria (MOB) in an Arctic permafrost active layer soil of the Lena Delta, Siberia. Applying denaturing gradient gel electrophoresis and cloning of $16 \mathrm{~S}$ ribosomal ribonucleic acid (rRNA) and pmoA gene fragments of active layer samples, we found a general restriction of the methanotrophic diversity to sequences closely related to the genera Methylobacter and Methylosarcina, both type I MOB. In contrast, we revealed a distinct species-level diversity. Based on phylogenetic analysis of the $16 \mathrm{~S}$ rRNA gene, two new clusters of MOB specific for the permafrost active layer soil of this study were found. In total, 8 out of 13 operational taxonomic units detected belong to these clusters. Members of these clusters were closely related to Methylobacter psychrophilus and Methylobacter tundripaludum, both isolated from Arctic environments. A dominance of MOB closely related to $M$. psychrophilus and $M$. tundripaludum was confirmed by an additional pmoA gene analysis. We used diversity indices such as the Shannon diversity index or the Chaol richness estimator in order to compare the MOB community near the surface and near the permafrost table. We determined a similar diversity of the MOB community in both depths and suggest that it is not influenced by the extreme physical and geochemical gradients in the active layer.
\end{abstract}

\footnotetext{
S. Liebner $(\bowtie) \cdot K$. Rublack $\cdot$ D. Wagner

Alfred Wegener Institute for Polar and Marine Research, Research Department Potsdam,

Telegrafenberg A43,

14473 Potsdam, Germany

e-mail: Susanne.Liebner@awi.de

T. Stuehrmann

Max Planck Institute for Marine Microbiology,

Celsiusstrasse 1,

28359 Bremen, Germany
}

\section{Introduction}

Aerobic methanotrophic bacteria (MOB) of the phylum Proteobacteria primarily contribute to the consumption of methane in terrestrial environments. The microbial conversion of methane into carbon dioxide was estimated to account for $30 \%$ to $90 \%$ in flooded rice fields $[1,2]$, for $13 \%$ to $38 \%$ of the methane produced in temperate and subarctic peat soils [13], and for $15 \%$ to more than $90 \%$ of the diffusive methane flux in wetlands [36, 47]. The group of MOB comprises the three families Methylococcaceae, Methylocystaceae, and Beijerinckiaceae [5, 9-12]. The only exception is Crenothrix polyspora, a filamentous, sheathed microorganism recently discovered to be methanotrophic [52]. Members of the Methylococcaceae are termed type I MOB and belong to the $\gamma$-subdivision of the Proteobacteria phylum. Members of the Methylocystaceae and Beijerinckiaceae are termed type II MOB and belong to the $\alpha$-subdivision of the Proteobacteria phylum [10-21]. The diversity and composition of MOB have been investigated in several environments such as freshwater sediments [8, 42], landfill soils [59], rice field soils [22, 24], habitats with only atmospheric methane concentrations $[29,33,35]$, and peat bogs with very low $\mathrm{pH}$ values [39, 40].

Northern wetlands and tundra contribute about $20 \%$ to the global natural methane emission annually $[6,7,18]$. Given that the global warming potential of methane on a molecular basis and a time horizon of 100 years is 23 -fold that of carbon dioxide [27], the ecology of the MOB community as the major sink for methane in these environments is of importance. Methanotrophic communities were found to be abundant and active also in cold environments such as, for example, northern peat lands, eastern Antarctica, and Fennoscandian deep ground waters 
[53]. It was reported that MOB are viable in deep Siberian permafrost sediments with ages of 1,000-100,000 years as well [32]. In addition, based on the temperature response of potential methane oxidation rates, it was recently shown that methane oxidizing bacteria are well adapted to the temperature regime in permafrost active layer soils of the Lena Delta [37]. However, our knowledge on MOB from high-latitude environments in terms of diversity and composition remains very poor [56].

With this study, we present first data on the methanotrophic diversity (richness and evenness) in Arctic tundra soils of the Lena Delta with steep gradients of temperature and methane. In addition to the $16 \mathrm{~S}$ ribosomal ribonucleic acid (rRNA) gene, we analyzed the phylogeny of the particulate methane monooxygenase gene (pmoA), known as a functional marker for MOB [40]. With this study, we will show to what extent the methanotrophic diversity is influenced by the harsh environmental conditions in Siberian permafrost active layer soils.

\section{Materials and Methods}

\section{Study Site}

The study site is located in the eastern part of Samoylov Island (N $72^{\circ} 22^{\prime}$, E $126^{\circ} 28^{\prime}$ ) in the Lena Delta, Siberia. For a detailed description of the geomorphology of the Lena Delta, refer to Schwamborn et al. [50]. During the expedition LENA 2005 (7th of July to 1st of September), active layer cores (ø $56 \mathrm{~mm}$ ) of a low-centered polygon were sampled. The cores were frozen immediately after sampling and were kept frozen until further processing. For this study, we used core number 33, sampled on the 25th of August, 2005, at the rim of the polygon. In the laboratory, the core was sectioned under sterile conditions, and samples of depths 6-11 (near surface) and 20-28 cm (near permafrost table) were selected for molecular analysis. The selection of these samples was according to a previously observed shift in the temperature optima of potential methane oxidation rates between the near surface and the near permafrost table within the active layer of the polygon rim [37].

\section{Soil and Pore Water Analysis}

Vertical profiles of soil $\mathrm{CH}_{4}$ concentrations were obtained from the elevated rim of the polygon through extraction of $\mathrm{CH}_{4}$ from soil pore water by injection of $5 \mathrm{ml}$ water into saturated $\mathrm{NaCl}$ solution, shaking the solution and subsequently analyzing the $\mathrm{CH}_{4}$ headspace concentration with gas chromatography. Soil temperature measurements (Greisinger GTH 100/2 equipped with Ni-Cr-Ni tempera- ture sensor) were carried out in $5-\mathrm{cm}$ increments from 0 to $38 \mathrm{~cm}$ soil depth before core sampling. The total carbon and total nitrogen $(\mathrm{TN})$ contents were determined with an automatic element analyzer (Elementar VARIO EL III). The total organic carbon (TOC) content was measured on corresponding samples after $\mathrm{HCl}(10 \%)$ acid digestion to remove the carbonate on the same analyzer (Elementar VARIO EL III). The $\mathrm{pH}$ values were determined with the MultiLab 540 (WTW, Germany) in pore water, which was extracted by applying Rhizons into undisturbed active layer samples according to the method of Seeberg-Elverfeldt et al. [51]. Cell counts of MOB were obtained based on fluorescence in situ hybridization with the MOB-specific probes $\mathrm{Mg} 705 / \mathrm{Mg} 84$ (type I MOB) and Ma450 (type II MOB) [15] according to a protocol described recently [37].

\section{Extraction of Total DNA}

Prior to the deoxyribonucleic acid (DNA) extraction, the core sections were thoroughly homogenized. Afterwards, four subsamples of each depth were used for extraction. Total genomic DNA was extracted with the UltraClean ${ }^{\mathrm{TM}}$ Soil and the PowerSoil ${ }^{\mathrm{TM}}$ DNA Isolation Kit (Mo Bio Laboratories, USA) following to the manufacture's protocol. Both kits combine heat, detergents, and mechanical force against beads to lyse microbial cells. The released DNA is then bound to a silica spin filter and finally purified. The PowerSoil ${ }^{\mathrm{TM}}$ DNA Isolation Kit is intended for use with environmental samples containing a high humic acid content. The size of the genomic DNA was checked by electrophoresis on a $1 \%$ agarose gel against a Lamda EcoRI/HindIII marker (ABgene, UK) with SYBR gold staining.

\section{PCR Amplification}

Polymerase chain reaction (PCR) amplification reactions were performed with a thermal cycler (iCycler, Bio-Rad, USA). PCR reaction mixes $(50 \mu$ for denaturing gradient gel electrophoresis [DGGE], $25 \mu \mathrm{l}$ for clone libraries) contained $1 \times$ PCR reaction buffer, $0.2 \mu \mathrm{M}$ primer, $0.25 \mu \mathrm{M}$ deoxyribonucleoside triphosphates, 1.25 U MasterTaq Polymerase (Eppendorf, Germany), and 5-30 ng template (in a 1:10 dilution). All reactions were optimized against $\mathrm{MgCl}_{2}$ and PCR enhancer solution (Eppendorf, Germany). PCR conditions were as follows: $94^{\circ} \mathrm{C}$ for $3 \mathrm{~min}$ (initial denaturation), followed by 30 cycles (DGGE analysis) or 20 cycles (clone libraries) with $30 \mathrm{~s}$ at $94^{\circ} \mathrm{C}, 1 \mathrm{~min}$ at $56^{\circ} \mathrm{C}$, and $3 \mathrm{~min}$ at $72^{\circ} \mathrm{C}$, and a final elongation at $72^{\circ} \mathrm{C}$ for $10 \mathrm{~min}$ (DGGE analysis) or $60^{\circ} \mathrm{min}$ (clone libraries). MOBspecific 16S rRNA gene sequences were amplified using the primer combinations MethT1b F/MethT1b R (type I MOB) and 27 F/MethT2 R (type II MOB). For the 
amplification of the $p m o A$ gene, a nested PCR approach (A189 F/A682 R followed by A189 F/mb661 R/A650 R) as suggested by Horz et al. [29] was compared with a direct PCR approach (A189 F/mb661 R/A650 R). Because the nested approach did not improve DGGE or cloning efficiency but was likely to increase PCR bias and contamination by amoA gene (encoding subunit A of the ammonia monooxygenase) sequences, the direct approach was chosen for the analysis. Primer details and references are listed in Table 1. PCR products were checked by electrophoresis on a $2 \%$ agarose gel against a 100-bp marker (MoBiTec, Germany) with SYBR gold staining. For DGGE, PCR products were purified with a QIAquick PCR Purification Kit (Qiagen, Germany). For clone libraries, PCR products in plates (96-well plates, ABgene) were purified by centrifugation $\left(980 \times g\right.$ at $\left.4^{\circ} \mathrm{C}\right)$ through Multi Screen 96-well plates (Millipore, USA) on a column of Sephadex ${ }^{\mathrm{TM}}$ G-50 Superfine powder (GE Healthcare BioScience, Sweden).

\section{Denaturing Gradient Gel Electrophoresis}

PCR products were separated on an $8 \%$ polyacrylamide gel in $1 \times$ Tris-acetate-ethylenediamine tetraacetic acid buffer using a D-Code System (Bio-Rad). The denaturing gradient (100\% denaturant consisted of $7 \mathrm{M}$ urea and of $40 \%, v / v$, deionized formamide) ranged from $30 \%$ to $60 \%$ and from $40 \%$ to $70 \%$, respectively. Gradient gel electrophoresis ran constantly at $100 \mathrm{~V}$ for $14 \mathrm{~h}$ at $60^{\circ} \mathrm{C}$. The gels were stained for $30 \mathrm{~min}$ with SYBR gold and visualized with a GeneFlash system (Syngene, UK). Distinct bands were excised with a sterile scalpel, eluted overnight at $4^{\circ} \mathrm{C}$, and reamplified with primers without GC-clamp in 20-25 cycles. Products were purified as described and sequenced by MWG (Germany).
Construction of Clone Libraries and Sequencing

The purified PCR products were ligated into the linear Plasmid Vector pCR4 supplied with the TOPO TA Cloning $^{\mathrm{R}} \mathrm{Kit}$ for Sequencing (Invitrogen, Germany) and subsequently transformed into chemically competent $E$. coli cells via heat shock following the manufacture's protocol. Cells were incubated overnight at $37^{\circ} \mathrm{C}$ on agar plates containing $0.05 \%$ Ampicillin. Only cells containing a Vector with the insert were competent to grow with ampicillin. Colonies of these cells were screened for correct size of the insert and directly sequenced. Sequencing was performed with the BigDye Terminator cycle sequencing kit, version 3.1 (Applied Biosystems, Germany) with vector primers.

\section{Sequence Analysis}

Sequences of the $16 \mathrm{~S}$ rRNA gene were automatically and manually edited with Sequencing Analysis 5.2 (Applied Biosystems) and checked for chimeras with Bellerophon [30] and with the Chimera-Check of the Ribosomal Database Project (Michigan State University). Contigs were assembled with Sequencher 4.7 (Gene Codes, USA). Sequences were imported into the ARB 16S rRNA database (www.arb-home.de) and phylogenetically analyzed. Rarefaction analysis and estimation of diversity indices were performed with DOTUR [49].

Previous to an analysis of the achieved $p m o A$ gene sequences, a database of $p m o A$ gene sequences was created using CLC Free workbench software (http:/www.clcbio. com). This database contains all translated pmo $A$ gene sequences of good quality (approximately 1,000 sequences) available in GenBank (http://www.ncbi.nlm.nih.gov/). The translated pmo $A$ gene sequences were aligned using the

Table 1 Methanotroph specific primers used in this study

\begin{tabular}{|c|c|c|c|c|c|}
\hline Target gene & $\begin{array}{l}\text { E. coli position }{ }^{\mathrm{a}} \\
\text { fragment length }(\mathrm{bp})^{\mathrm{b}}\end{array}$ & Primer $^{\mathrm{c}}$ & Sequence $^{\mathrm{f}}$ & Annealing $\left({ }^{\circ} \mathrm{C}\right)$ & Reference \\
\hline \multirow[t]{4}{*}{ 16S rRNA } & $84-102$ & MethT1bF ${ }^{d}$ & 5'-CCT TCG GGM GCY GAC GAGT-3' & 56 & [59] \\
\hline & $988-1,006$ & MethT1bR & 5'-GAT TCY MTG SAT GTC AAGG-3' & & [59] \\
\hline & $27-46$ & $27 \mathrm{~F}^{\mathrm{d}, \mathrm{e}}$ & 5'-GAG TTT GAT CMT GGC TCA G-3' & & [34] \\
\hline & $997-1017$ & MethT2R $^{\mathrm{e}}$ & 5'-CAT CTC TGR CSA YCA TAC CGG-3' & & [59] \\
\hline \multirow[t]{4}{*}{ pmoA } & & $\mathrm{A} 189 \mathrm{~F}^{\mathrm{d}}$ & 5'-GGN GAC TGG GAC TTC TGG-3' & 56 & {$[26]$} \\
\hline & 493 & A682 R & 5'-GAASGCNGAGAAGAASGC-3 & & {$[26]$} \\
\hline & 472 & Mb661 R & 5'-CCG GMG CAA CGT CYTTACCC-3' & & [8] \\
\hline & 461 & A650 R & 5'-ACG TCC TTA CCG AAG GT-3' & & {$[3]$} \\
\hline
\end{tabular}

\footnotetext{
${ }^{\text {a }}$ Refers to $16 \mathrm{~S}$ rRNA gene primers

${ }^{\mathrm{b}}$ Refers to $p m o A$ gene primers

"Primer combinations are given in "Materials and Methods"

'GC clamp for DGGE: 5'-CGC CCG CCG CGC GCG GCG GGC GGG GCG GGG GCA CGG GGG G-3'

${ }^{\mathrm{e}}$ Increasing annealing time: 45, 60, and $90 \mathrm{~s}$ according to Wise et al. [59]

${ }^{\mathrm{f}} N$ Bases A, C, T, or G, $M$ bases A or C, $Y$ bases $\mathrm{C}$ or $\mathrm{Z}, S$ bases $\mathrm{G}$ or $\mathrm{C}$
} 
MUSCLE algorithm [14]. Database and alignment were imported into the ARB program. The pmoA sequences obtained in this study were translated with CLC Free workbench, imported into the newly created pmo $A$ gene database, manually aligned, and phylogenetically analyzed.

Nucleotide and Protein Sequence Accession Numbers

The 16S rRNA and pmoA gene sequences recovered in this study and used for phylogenetic presentation have been deposited in the European Molecular Biology Laboratory, GenBank, and DNA Data Bank of Japan nucleotide sequence databases under the accession numbers EU124838-56 (16S rRNA gene sequences) and EU124857-EU124864 and EU135968 (pmoA gene sequences).

\section{Results}

\section{Soil and Pore Water Characteristics}

The soil of the polygon rim was characterized by a soil texture of silty and loamy sand, a low water level leading to oxic conditions in the top soil compared to the bottom, and a limited organic matter accumulation. This was reflected by relatively low contents of TOC (1.2-3.0\%) and TN (approx. 0.1\%). During the summer months, the active layer, furthermore, showed distinct gradients in temperature, which decreased from the top to the bottom (8.8$0.9^{\circ} \mathrm{C}$ ) and methane concentration, which increased with soil depth (52.1-176.5 $\left.\mathrm{nmol} \mathrm{g}^{-1}\right)$. The $\mathrm{pH}$ was slightly acidic to almost neutral (6.1-6.5). The values of TOC, TN, $\mathrm{pH}$, methane, and temperature are summarized in Table 2. Cell counts of type I MOB varied between $1.6 \times 10^{7}( \pm 4.7 \times$ $\left.10^{6}\right)$ cells $g^{-1}$ soil near the surface and $7.5 \times 10^{6}\left( \pm 1 \times 10^{6}\right)$ cells $\mathrm{g}^{-1}$ soil near the permafrost table. In contrast, cell counts of type II MOB were below the detection limit that was at $2.4 \times 10^{4}$ cells $\mathrm{g}^{-1}$ soil according to the high dilution necessary to obtain low autofluorescence of the mineral and organic soil matter.
Diversity of Aerobic Methanotrophic Bacteria Based on the $16 \mathrm{~S}$ rRNA Gene

The amplification of the $16 \mathrm{~S}$ rRNA gene using methanotroph-specific primers revealed only sequences of the type I MOB but not of the type II MOB. The DGGE profiles of these 16S rRNA gene sequences of both depths showed only a few bands (Fig. 1a). Two distinct bands of the nearsurface samples and three of the near-permafrost table samples were excised and sequenced. In Table 3, the sequences are assigned to the according bands in the DGGE gel, and their phylogenetic relatedness is summarized. Briefly, both depths were represented by members of the genera Methylobacter and Methylosarcina belonging to the $\gamma$-subdivision of the Proteobacteria phylum (type I methanotrophs). In both depths, the closest cultured relatives of the obtained sequences were Methylobacter psychrophilus, Methylosarcina quisquiliarum, and Methylosarcina fibrata. In addition, one sequence of the near permafrost table was most closely related to Methylobacter tundripaludum.

For clone library analysis, 55 sequences were used in total, 35 belonging to the near-surface samples and 20 belonging to the near-permafrost table samples. In total, 13 operational taxonomic units (OTUs) were identified ( $\geq 98 \%$ sequence similarity). Except for one OTU grouping within the Methylosarcina genus, they were all closely related to the Methylobacter genus. Again, no type II methanotrophs could be detected. Considering both depths separately, nine OTUs were detected near the surface and eight near the permafrost table. Of all OTUs, five were restricted to the near-surface and four to the near-permafrost table samples. The phylogenetic affiliation of selected sequences representing the different OTUs is shown in Fig. 2. According to this, the OTUs group in four clusters (clusters I to IV). Clusters I and II are specific for the active layer studied here and show a distinct microdiversity. These clusters consist of three and five OTUs, respectively, corresponding to 41 out of 55 sequences in total. Sequences of these clusters are greater than $3 \%$ and less than $10 \%$ different

Table 2 Selected soil properties of the elevated polygonal rim on Samoylov Island, Lena Delta (values of methane concentrations and temperatures were obtained in the field in July, 2005)

\begin{tabular}{lccccc}
\hline Depth $(\mathrm{cm})$ & $\mathrm{pH}$ & TOC $(\%)$ & $\mathrm{TN}(\%)$ & $\mathrm{CH}_{4}\left(\mathrm{nmol} \mathrm{g}^{-1}\right)$ \\
\hline $0-6$ & 6.5 & 3.0 & 0.2 & 52.1 & 8.8 \\
$6-11$ & 6.5 & 2.1 & 0.1 & 56.2 & 5.2 \\
$11-18$ & 6.3 & 2.3 & 0.1 & 59.5 & 3.5 \\
$18-25$ & 6.4 & 2.0 & 0.1 & 140.6 & 2.4 \\
$25-32$ & 6.3 & 1.2 & 0.0 & n.d. & n.d. \\
$32-38$ & 6.1 & 2.8 & 0.1 & & 0.9 \\
\hline
\end{tabular}

n.d. Not determined 


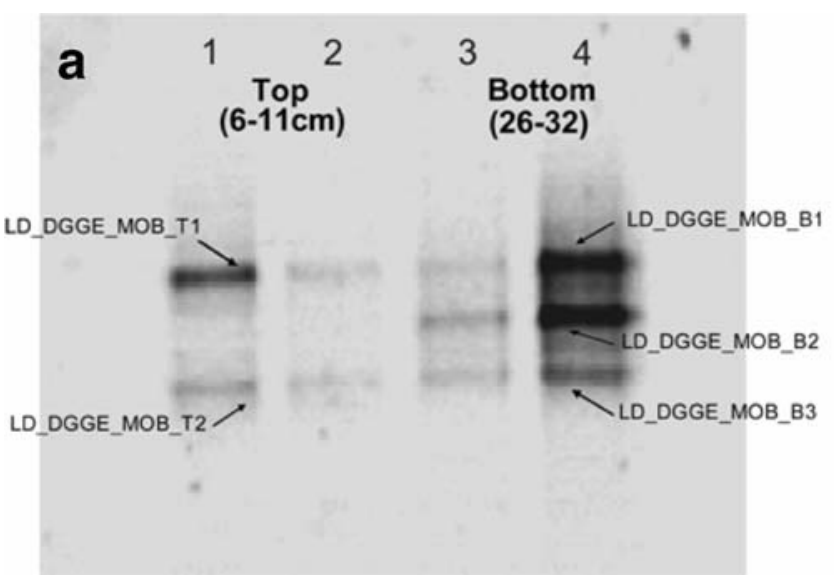

Figure 1 DGGE profiles of aerobic methanotrophic bacteria from active layer samples of Samoylov Island, Lena Delta. a Methanotrophspecific 16S rRNA gene fragments of near-surface (Top, lines 1 and 2) and near-permafrost table (Bottom, lines 3 and 4 ) samples and b pmoA

from M. psychrophilus and M. tundripaludum as their closest cultured relatives. The OTU of cluster III is directly affiliated to $M$. psychrophilus and $M$. tundripaludum. OTUs of cluster IV are directly affiliated to M. fibrata and $M$. quisquiliarum and are closely related to Methylomicrobium buryatense.

At the species level ( $\geq 98 \%$ sequence similarity), we detected a distinct overall diversity based on the Shannon index (2.22) that was similar near the surface and near the permafrost table (1.90). In addition, the overall evenness based on the Simpson index was almost equal in both depths $(0.14$ near the surface compared to 0.12 near the permafrost table). All diversity indices are summarized in Table 4. According to the estimated species richness (Chaol and ACE estimators), overall coverage and coverage values of the near-surface and near-permafrost table libraries were high $(76-100 \%)$. This is also reflected in the respective rarefaction curves (Fig. 3). Figure 3a

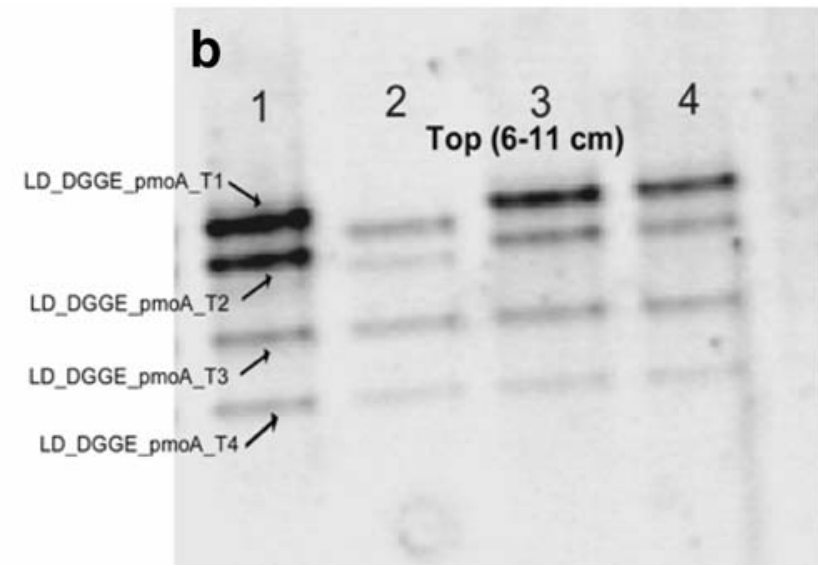

gene fragments of near-surface samples (lines 1-4). Arrow-marked bands were excised and sequenced. Lines with bands that were not chosen for sequencing are shown to prove analytical reproducibility of the DGGE profiles

includes an interpolation of the total rarefaction curve. It emphasizes that with 55 clones, we detected greater than $70 \%$ of the estimated richness of OTUs and that at least 100 more clones would be necessary to gain four OTUs more.

At the genus level ( $\geq 95 \%$ sequence similarity) [48], the overall diversity decreased significantly. Based on the Shannon index, it was only half of that at the species level. In addition, the estimated overall richness at the genus level was only $30 \%$ that of the species level.

\section{Phylogenetic Analysis of the pmoA Gene}

In addition to the diversity of MOB in active layer samples of two depths of a Siberian permafrost active layer soil based on the 16S rRNA gene, we investigated the distribution and phylogenetic relatedness of pmoA gene sequences in the same samples.

Table 3 Phylogenetic characterization of 16S rRNA gene sequences of aerobic methanotrophic bacteria of active layer samples from Samoylov Island, Lena Delta, obtained through DGGE

\begin{tabular}{|c|c|c|c|c|}
\hline $\begin{array}{l}\text { Sequence } \mathrm{ID}^{\mathrm{a}} \\
\text { (sequence length) }\end{array}$ & $\begin{array}{l}\text { Next cultured relative } \\
\text { according to NCBI }\end{array}$ & $\begin{array}{l}\text { Accession number, } \\
\text { GenBank }\end{array}$ & $\begin{array}{l}\text { Similarity according } \\
\text { to NCBI BLAST }{ }^{\mathrm{b}}(\%)\end{array}$ & $\begin{array}{l}\text { Similarity according } \\
\text { to } \mathrm{NJ}^{\mathrm{c}}(\%)\end{array}$ \\
\hline LD_DGGE_MOB_T1 (826 bp) & Methylobacter psychrophilus & AF152597 & 98 & 99 \\
\hline \multirow[t]{2}{*}{ LD_DGGE_MOB_T2 (829 bp) } & Methylosarcina fibrata & AF177296 & 99 & 99 \\
\hline & Methylosarcina quisquiliarum & AF177297 & 98 & 98 \\
\hline LD_DGGE_MOB_B1 (855 bp) & Methylobacter psychrophilus & AF152597 & 97 & 97 \\
\hline LD_DGGE_MOB_B2 (846 bp) & Methylobacter tundripaludum & AJ414655 & 98 & 99 \\
\hline \multirow[t]{2}{*}{ LD_DGGE_MOB_B3 (753 bp) } & Methylosarcina fibrata & AF177296 & 99 & 99 \\
\hline & Methylosarcina quisquiliarum & AF177297 & 98 & 98 \\
\hline
\end{tabular}

\footnotetext{
${ }^{\text {a } A c c o r d i n g ~ t o ~ F i g . ~} 1, T$ top, $B$ bottom

${ }^{\mathrm{b}}$ Nucleotide-nucleotide query, BLASTN algorithm

${ }^{\mathrm{c}} N J$ Neighbor-joining algorithm (distance matrix) with Felsenstein correction [16]
} 
Figure 2 Phylogenetic tree showing the relation of $16 \mathrm{~S}$ rRNA gene sequences of aerobic methanotrophic bacteria from active layer samples of Samoylov Island, Lena Delta, to most closely branching $16 \mathrm{~S}$ rRNA gene sequences of known methanotrophic isolates and to sequences of selected methanotrophic isolates as references.

The 16S rRNA gene sequences shown here were selected according to their affiliation to 13 different OTUs detected in this study. The tree represents a maximum likelihood tree based on the SILVA Ref dataset (www.arb-silva.de) and was calculated according to the PhyML algorithm [20] using a $50 \%$ filter for range of the PCR product specific for Methylococcaceae. We abstained from bootstrapping. $L D$ Lena Delta, Top near-surface samples, Bottom nearpermafrost table samples

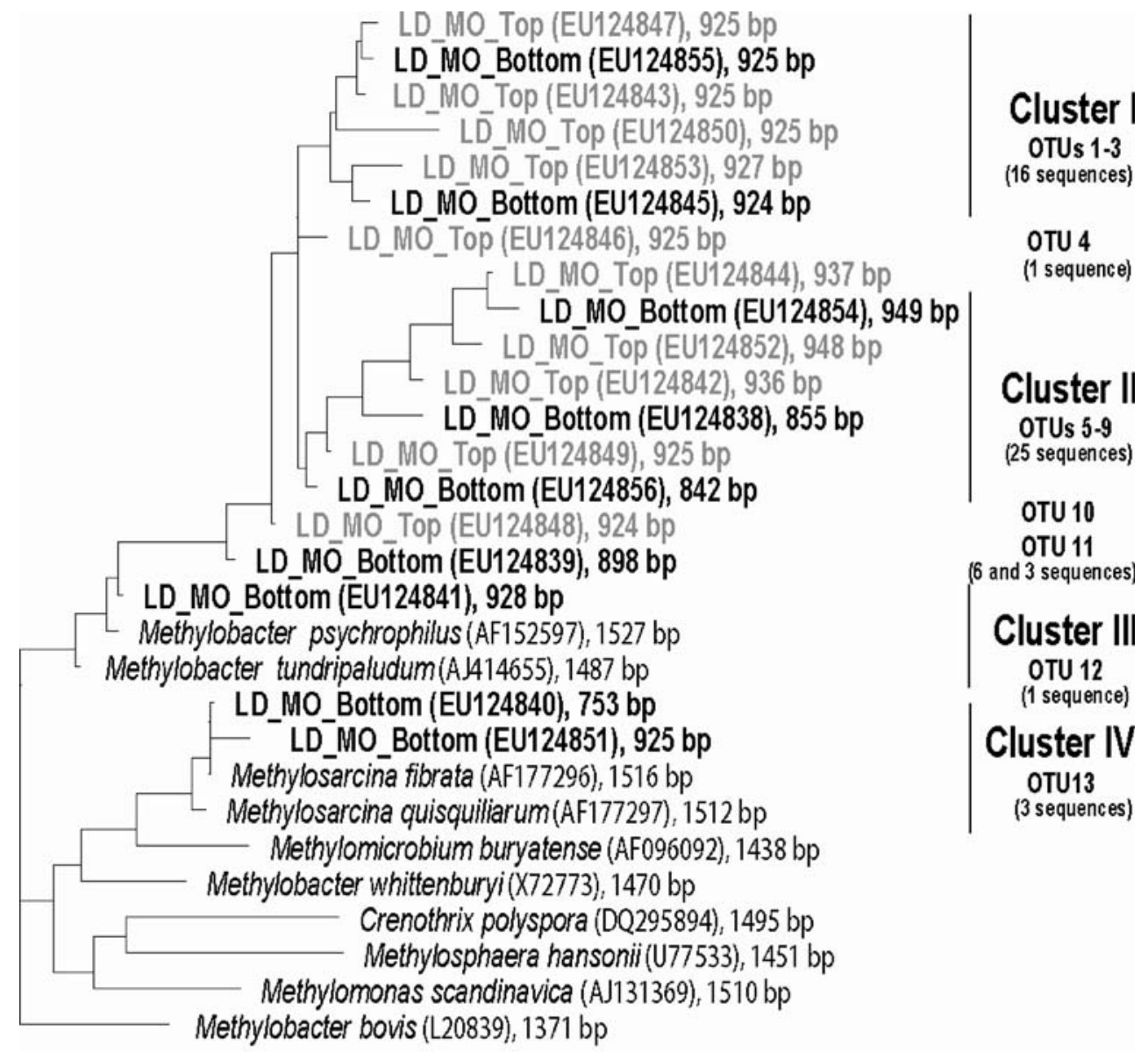

0.10

Table 4 Diversity indices of 16S rRNA gene sequences of aerobic methanotrophic bacteria in active layer samples from Samoloy Island, Lena Delta

\begin{tabular}{|c|c|c|c|c|c|c|c|}
\hline & \multirow[t]{3}{*}{$\mathrm{DI}^{\mathrm{a}}$} & \multicolumn{2}{|l|}{ Total $^{\mathrm{b}}$} & \multicolumn{2}{|l|}{ Top } & \multicolumn{2}{|l|}{ Bottom } \\
\hline & & \multicolumn{6}{|c|}{ Sequence similarity } \\
\hline & & $98 \%$ & $95 \%$ & $98 \%$ & $95 \%$ & $98 \%$ & $95 \%$ \\
\hline & Shannon & 2.22 & 1.01 & 1.90 & 0.81 & 1.90 & 1.12 \\
\hline & Min, $\max ^{\mathrm{c}}$ & $2.2,2.5$ & $1.0,1.4$ & $1.7,2.1$ & $0.6,0.9$ & $1.6,2.2$ & $0.7,1.6$ \\
\hline & Simpson & 0.10 & 0.34 & 0.14 & 0.45 & 0.12 & 0.41 \\
\hline & Chaol & 17 & 5 & 9 & 3 & 8 & n.d. ${ }^{\mathrm{d}}$ \\
\hline & Min, $\max { }^{c}$ & 14,37 & 5, n.d. ${ }^{\mathrm{d}}$ & 8,22 & 3, n.d. ${ }^{\text {d }}$ & 8,12 & \\
\hline & $\mathrm{ACE}$ & 17 & 5 & 10 & n.d. ${ }^{\mathrm{d}}$ & 9 & n.d. ${ }^{\mathrm{d}}$ \\
\hline & Min, $\max { }^{c}$ & 15,25 & 5,13 & 9,17 & & 8,18 & \\
\hline \multirow[t]{4}{*}{ Coverage $(\%)$} & Chao1 & 76 & 100 & 100 & 100 & 100 & n.d. ${ }^{\mathrm{d}}$ \\
\hline & Min, $\max { }^{c}$ & 35,92 & n.d. ${ }^{\mathrm{d}}, 100$ & $41,112.5$ & 100, n.d. $^{\mathrm{d}}$ & 66,100 & \\
\hline & $\mathrm{ACE}$ & 76 & 100 & 90 & n.d. ${ }^{\mathrm{d}}$ & 88 & n.d. ${ }^{\mathrm{d}}$ \\
\hline & Min, $\max { }^{c}$ & 52,86 & 38,100 & 52,100 & & 44,100 & \\
\hline
\end{tabular}

${ }^{a}$ Diversity index, calculated with DOTUR [49], neighbor-joining algorithm (distance matrix) with Felsenstein correction [16], Diversity indices are based on 16S rRNA gene sequences from clone libraries only

${ }^{\mathrm{b}}$ Sequences near the surface (Top) and near the permafrost table (Bottom)

${ }^{c}$ According to confidence interval of $95 \%$

${ }^{\mathrm{d}}$ Not determined 

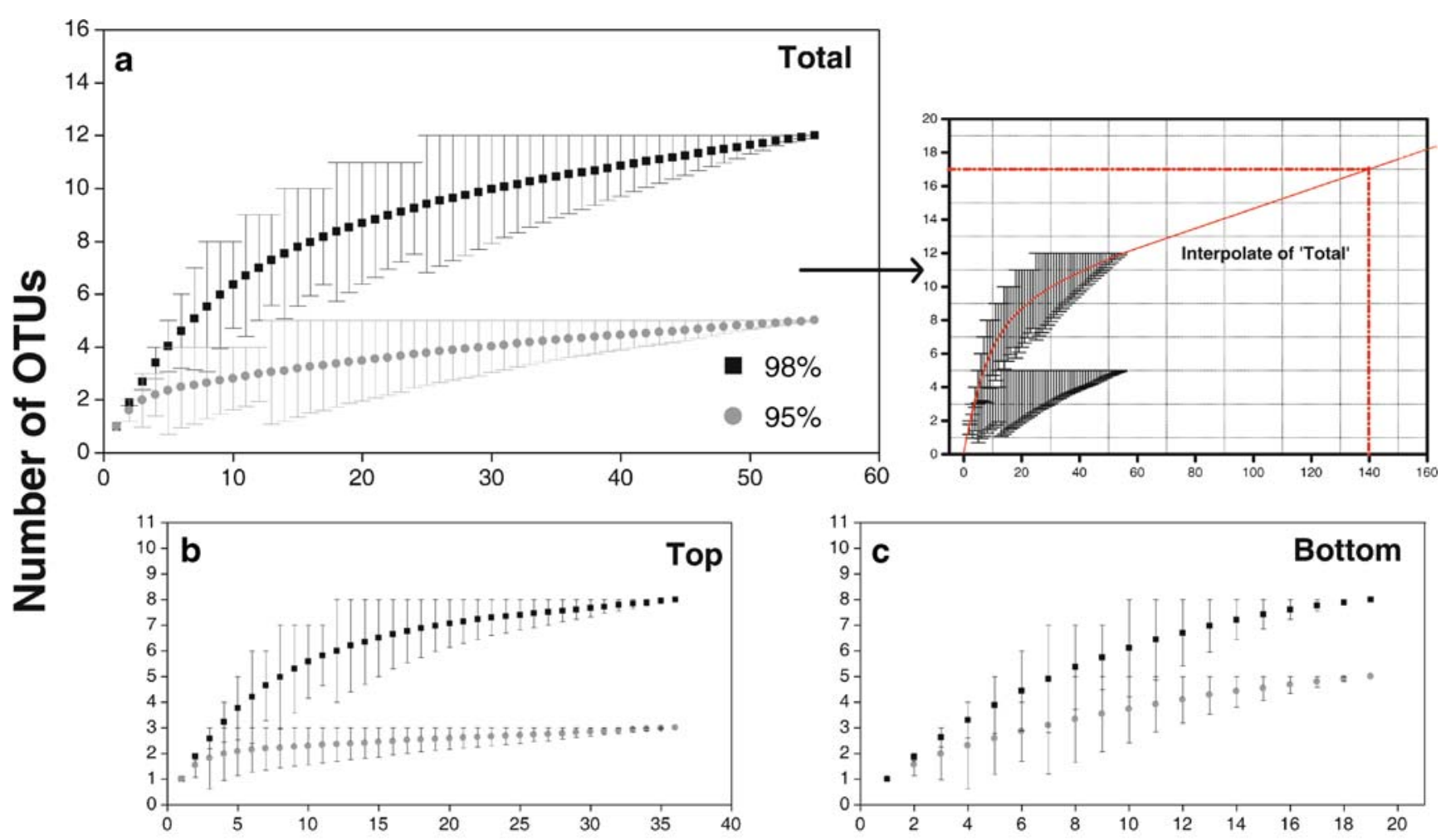

\section{Number of Individuals}

Figure 3 Rarefaction curves of 16S rRNA gene sequences of aerobic methanotrophic bacteria from active layer samples of Samoylov Island, Lena Delta. Graphs show a comparison between $98 \%$ and $95 \%$ sequence similarity of a near surface + near permafrost table

DGGE profiles of the $p m o A$ gene could only be obtained for the near-surface samples. We reproducibly detected four distinct bands (Fig. 1b) that were excised and sequenced. DGGE bands of the near-permafrost table samples could not be excised and sequenced successfully as a result of very low amounts of template. For this reason and in order to confirm the DGGE results of the near-surface samples, we constructed small clone libraries of the pmoA gene for the near-surface and the near-permafrost table samples. We obtained 18 clones that gave five additional pmoA gene sequences different from the previous ones.

The distribution and phylogeny of the $p m o A$ gene sequences was consistent to the distribution and phylogeny of the $16 \mathrm{~S}$ rRNA gene sequences. Again, we did not detect $p m o A$ gene sequences belonging to the type II group of MOB, and the phylogenetic distribution of sequences was restricted (Fig. 4). The $p m o A$ gene sequences obtained in this study grouped in four clusters (clusters I to IV in the tree). The sequence similarity of the representatives of clusters I and II to $M$. psychrophilus and M. tundripaludum was greater than $80 \%$. The sequence similarity of representatives of cluster III to $M$. buryatense was greater than $80 \%$. Representative sequences of cluster IV were less than $80 \%$ similar to any known isolate. samples, arrow marks interpolated number of clones necessary to obtain estimated species richness of 17 OTUs, $\mathbf{b}$ only near-surface and c only near-permafrost table samples. Error bars, confidence interval of $95 \%$

\section{Discussion}

Our results showed that members within the type I MOB were closely related to only two known genera, Methylobacter and Methylosarcina. This was consistently detected applying two different methods, DGGE and cloning. Given that altogether ten genera belong to the type I MOB [5, 25, 45, 54, 60], this points at a restricted diversity within the studied community of this group. In terms of relative abundance, representatives related to the Methylobacter genus were clearly dominant, whereas the number of representatives of the Methylosarcina genus was only marginal. In a related study on high-arctic sediments based on DGGE profiles, the MOB community was also found to be restricted to only two genera [57]. In that study, members of the genera Methylobacter and Methylosinus and consequently both type I and type II MOB were detected. Similar to our study members of the Methylobacter genus were recovered to be dominant.

A low diversity or a restriction to certain groups of MOB was reported also for nonarctic environments that exhibit extreme environmental conditions. The MOB community of peat bogs or acidic forest soils, for example, was restricted to members of type II MOB [39, 40, 43]. Besides, all known 


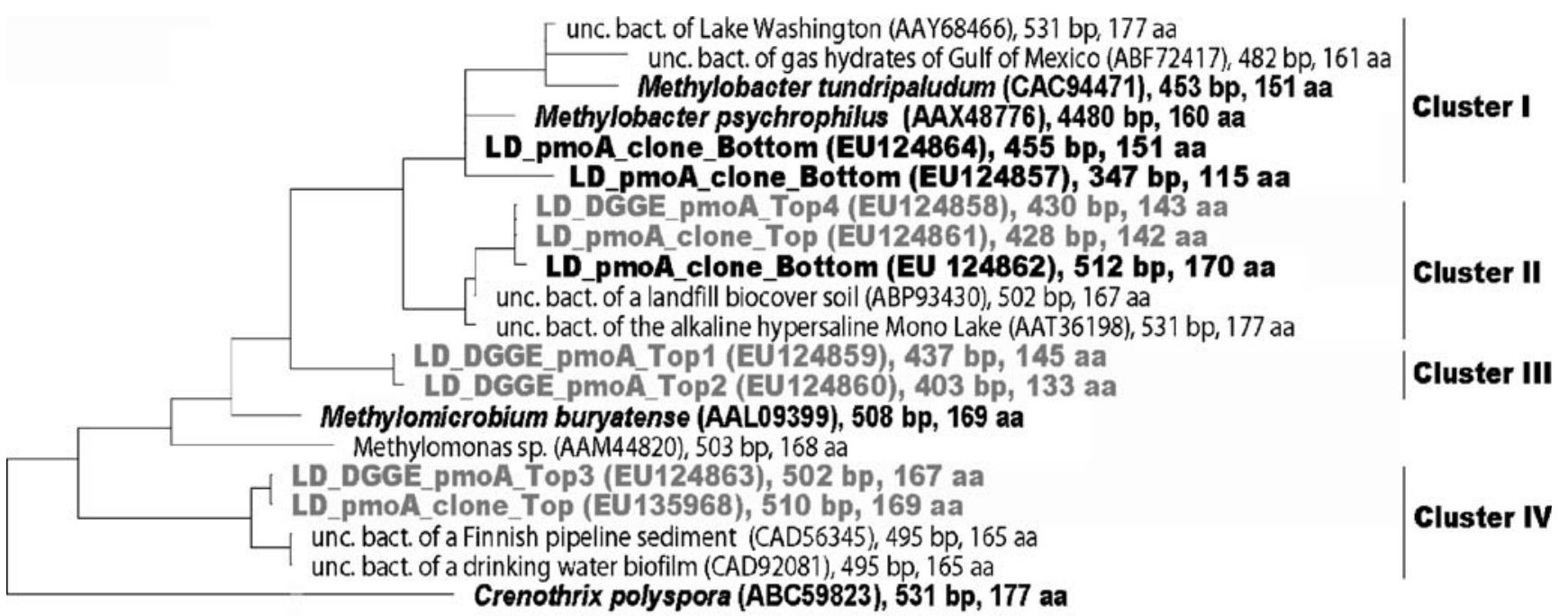

0.10

Figure 4 Phylogenetic tree showing the relation of representative amino acid sequences (translated $p m o A$ gene sequences) from active layer samples of Samoylov Island, Lena Delta, to most closely branching pmo $A$ gene sequences of cultured and uncultured aerobic methanotrophic bacteria and to Crenothrix polyspora (outgroup sequence). The tree

acidophilic isolates belong to the genera Methylocapsa and Methylocella, both type II MOB [9-12]. The MOB community capable of the consumption of atmospheric methane was studied in different forest and grassland soils and was found to exclude members of the type I group. It was suggested to consist primarily of type II MOB [35] and also of distinct, uncultivated clades distant from type I and type II MOB [23, 29, 33, 46]. In all studies discussed, the MOB community is exposed to environmental extremes such as freeze-thaw cycles, low $\mathrm{pH}$ values, or low substrate concentrations and was found to be restricted to certain taxonomic groups of $\mathrm{MOB}$. In contrast to that, a wide range of MOB genera of both type I and type II MOB was reported for more moderate environments such as landfill soils [59], rice field soils [22, 24, 28], freshwater sediments [8, 42, 44], and subarctic tundra soils [31]. This points at a trend toward a restricted diversity or a selection for certain groups of MOB in more extreme environments, which is in accordance with the results obtained in the present study.

The absence of type II MOB in our study on the $16 \mathrm{~S}$ rRNA as well as on the pmoA gene level confirms a previous study indicating a clear dominance of type I over type II MOB in active layer samples from Samoylov Island using phospholipid fatty acid (PLFA) analysis [55]. Our methodological approach is based on primer combinations that were designed to detect both $16 \mathrm{~S}$ rRNA and pmoA gene sequences of known and unknown type $\mathrm{I}$ as well as type II MOB [3, 8, 59]. These primer combinations were used in several studies where type I and type II MOB were detected either based on the 16S rRNA gene [57], based on represents a maximum likelihood tree calculated according to the PhyML algorithm [20] using a 30\% filter (amino acid position 63-201). We abstained from bootstrapping. $L D$ Lena Delta, Top near-surface samples, Bottom near-permafrost table samples, $D G G E$ pmoA sequences obtained through DGGE, pmoA_clone sequences through clone libraries

the pmoA gene [29, 42], or based on both genes [28, 44]. According to this, we would have detected type II MOB if their abundance was sufficiently high. However, type II MOB were below the detection limit in the studied permafrost active layer soil, while cell counts of type I MOB were in the range of $10^{7}$ cells $\mathrm{g}^{-1}$ soil. The unsuccessful amplification of type II MOB could therefore be due to a PCR bias against this group of MOB as an artifact caused by a too low abundance of type II MOB in our samples. Previous studies showed that true psychrophilic MOB can be only found within the subgroup of type I MOB [4, 41], which is in accordance with in situ temperatures of permafrost environments. Considering this and the fact that type II MOB outcompete type I MOB only at either extremely low methane concentrations as discussed in the beginning or at distinctly heightened methane concentrations [38], it is evident that the environmental conditions of the Siberian permafrost lead to the dominance of type I MOB over type II species.

Based on 16S rRNA gene clone libraries, we found a distinct species-level diversity of the type I MOB within the active layer including two new clusters (clusters I and II) of MOB that were specific for the permafrost active layer soil studied here. More than $60 \%$ of all OTUs and more than $70 \%$ of all sequences detected belong to these clusters. Specific clusters for Siberian permafrost-affected soils based on the 16S rRNA gene could already be detected for other groups of microorganisms such as methanogenic archaea [19], which was interpreted as clusters formed by methanogens characterized by a specific adaptation to the 
harsh permafrost conditions. The closest cultured relatives of members of the clusters detected here were $M$. psychrophilus and M. tundripaludum. M. psychrophilus was isolated from Siberian tundra and was characterized as a true psychrophile with an optimum growth temperature between $3.5^{\circ} \mathrm{C}$ and $10^{\circ} \mathrm{C}$ [41]. M. tundripaludum was isolated from an Arctic wetland soil on the island of Svalbard, Norway, and was characterized as a psychrotroph [58]. The sequence similarity of representatives of clusters I and II to M. psychrophilus and M. tundripaludum was less than $95 \%$. Considering the $16 \mathrm{~S}$ rRNA sequence similarity only, these clusters can be distinguished from known genera [48].

Our additional analysis of the phylogeny and distribution of the pmoA gene revealed a remarkable congruence with the phylogeny of the 16S rRNA gene sequences. The pmoA cluster I coincided with the two specific 16S rRNA gene permafrost clusters (clusters I and II), whereas pmoA cluster II confirmed cluster III in the $16 \mathrm{~S}$ rRNA tree. The first group of sequences was directly affiliated to the species $M$. psychrophilus and M. tundripaludum. The second group of sequences was not directly affiliated to any known species, but the closest cultivated relatives were again M. psychrophilus and M. tundripaludum. Based on this, the majority of MOB detected in this study was found to be closely related to phsychrophilic and psychrotrophic MOB isolated from Arctic environments. In addition, there is indication of a vertical shift in MOB population. Based on the 16S rRNA gene sequences, clusters III and IV are exclusively bottom. With respect to the pmoA gene sequences, cluster I is exclusively bottom, too, whereas III and IV are top. Although it is difficult to deduce a straight phylogenetic relationship between the distinct clusters of environmental sequences detected, the similarity in the 16S rRNA and pmo $A$ gene sequence clustering suggest that species of the same type I lineages were detected by both approaches. In addition, the comparison of the diversities obtained by analysis of both genes covered similar ranges.

Based on our data, we were able to compare the diversity of the active layer MOB near the surface and near the permafrost table. This comparison was necessary as we were aiming at investigating whether the gradients of temperature and methane within the active layer influence the diversity of the MOB community. Although, compared to the near surface, the active layer zone close to the permafrost table is characterized by a negative redox potential [17], by temperatures constantly below $2^{\circ} \mathrm{C}$, and significantly lower cell counts of MOB [37], diversity and estimated richness values were found to be almost equal in both depths. Thus, the gradients within the studied active layer do not seem to influence the diversity of the MOB, although they do influence their abundance and, as discussed before, most likely their community structure.
This indicates that, firstly, the gradients within the active layer are too weak to affect the diversity of the MOB community. Secondly, diversity and abundance must be regulated by different parameters. This is in accordance with results obtained from the phospholipid biomarker analysis. The PLFA distribution of near-surface and nearpermafrost horizons of the active layer showed that the microbial communities of both horizons do not incorporate significantly more unsaturated fatty acids under cooler conditions (Mangelsdorf and Wagner, personal communication). This indicates a high level of adaptation to low temperatures of permafrost microbial communities in general.

\section{Conclusions}

With this study, we present first data on the diversity of the MOB community in an Arctic permafrost affected environment from northeast Siberia at a high phylogenetic resolution. The spatial and temporal "snapshot" of methanotroph diversity presented here revealed a community of MOB that is specialized to the extreme environment it is exposed to. We showed that, in contrast to a distinct species-level diversity, the diversity of the MOB community at a higher taxonomic level is restricted to members closely related to only two known genera. The presented data support a trend reported in other studies toward a restricted diversity of MOB in more extreme environments. In the context of the climatic changes presently affecting the Siberian Arctic and its polygonal tundra landscapes, a restricted diversity could negatively affect the community of MOB and their function as a primary sink for methane in these regions.

Acknowledgments The authors acknowledge J. Harder (Max Planck Institute for Marine Microbiology) for helpful discussions and T. Sachs (Alfred Wegener Institute for Polar and Marine Research) for critical reading of the manuscript. In addition, we want to thank the crew of the Expedition LENA 2005, in particular Waldemar Schneider for logistic and Günter "Molo" Stoof for technical support (both Alfred Wegener Institute for Polar and Marine Research). Finally, we thank all our Russian partners, in particular Dimitry Yu. Bolshiyanov (Arctic Antarctic Research Institute), Alexander Yu. Dereviagin (Moscow State University), Mikhail N. Grigoriev (Permafrost Institute Yakutsk), Dmitri V. Melnitschenko (Hydro Base Tiksi), and Alexander Yu. Gukov (Lena Delta Reserve). This research was conducted on the frame of the International Max Planck Research School for Marine Microbiology (MarMic).

Open Access This article is distributed under the terms of the Creative Commons Attribution Noncommercial License which permits any noncommercial use, distribution, and reproduction in any medium, provided the original author(s) and source are credited. 


\section{References}

1. Bosse U, Frenzel P (1997) Activity and distribution of methaneoxidizing bacteria in flooded rice soil microcosms and rice plants (Oryza sativa). Appl Environ Microbiol 63:1199-1207

2. Bosse U, Frenzel P (1998) Methane emissions from rice-microcosms - the balance of production, accumulation and oxidation. Biogeochemistry 41:199-214

3. Bourne DG, McDonald IR, Murrell JC (2001) Comparison of pmoA PCR Primer sets as tools for investigating methanotroph diversity in three Danish soils. Appl Environ Microbiol 67:3802-3809

4. Bowman JP, McCammon SA, Skerratt MG (1997) Methylosphaera hansonii gen. nov., sp. nov., a psychrophilic, group I methanotroph from Antarctic, marine salinity, meromictic lakes. Microbiology (UK) 143:1451-1459

5. Bowman JP (1999) The Methanotrophs - the families Methylococcaceae and Methylocystaceae. In: Dworkin M (eds) The prokaryotes. Springer, New York

6. Cao M, Marshall S, Gregson K (1996) Global carbon exchange and methane emission from natural wetlands: application of a process-based model. J Geophys Res 101:14399-14414

7. Christensen TR, Prentice IC, Kaplan J, Haxeltine A, Sitch S (1996) Methane flux from northern wetlands and tundra: An ecosystem source modelling approach. Tellus Chem Phys Meteorology 48B:652-661

8. Costello AM, Lidstrom ME (1999) Molecular characterization of functional and phylogenetic genes from natural populations of methanotrophs in lake sediments. Appl Environ Microbiol 65:5066-5074

9. Dedysh SN, Liesack W, Khmelenina VN, Suzina NE, Trotsenko YA, Semrau JD, Bares AM, Panikov NS, Tiedje JM (2000) Methylocella palustris gen. nov., sp. nov., a new methane oxidizing acidophilic bacterium from peat bogs, representing a novel subtype of serine-pathway methanotrophs. Int J Syst Evol Microbiol 50:955-969

10. Dedysh SN, Horz H-P, Dunfield PE, Liesack W (2001) A novel pmoA lineage represented by the acidophilic methanotrophic bacterium Methylocapsa acidiphila B2. Arch Microbiol 177:117-121

11. Dedysh SN, Khmelenina VN, Suzina NE, Trotsenko YA, Semrau JD, Liesack W, Tiedje JM (2002) Methylocapsa acidiphila gen. nov., sp. nov., a novel methane-oxidizing and dinitrogen-fixing acidophilic bacterium from Sphagnum bog. Int J Syst Evol Microbiol 52:251-261

12. Dedysh SN, Berestovskaya YY, Vasilieva LV, Belova SE, Khmelenina VN, Suzina NE, Trotsenko YA, Liesack W, Zavarzin GA (2004) Methylocella tundrae sp.nov., a novel methanotrophic bacterium from acidic tundra peatlands. Intern J Syst Evol Microbiol 54:151-156

13. Dunfield P, Knowles R, Dumont R, Moore T (1993) Methane production and consumption in temperate and subarctic peat soils: response to temperature and $\mathrm{pH}$. Soil Biol Biochem 25:321-326

14. Edgar RC (2004) MUSCLE: multiple sequence alignment with high accuracy and high throughput. Nucleic Acids Res 32:1792-1797

15. Eller G, Stubner S, Frenzel P (2001) Group-specific 16 rRNA targeted probes for detection of type I and type II methanotrophs by fluorescence in situ hybridisation. FEMS Microbiol Lett 198:91-97

16. Felsenstein J (1989) PHYLIP-Phylogeny Inference Package (version 3.2). Cladistics 5:164-166

17. Fiedler S, Wagner D, Kutzbach L, Pfeiffer EM (2004) Element redistribution along redox gradients of low-centred-polygons, Lena Delta, Northern Siberia. Soil Sci Soc Am J 68:1002-1011

18. Fung I, John J, Lerner J, Matthews E, Prather M, Steele LP, Fraser PJ (1991) Three-dimensional model synthesis of the global methane cycle. J Geophys Res 96:13033-13065
19. Ganzert L, Jurgens G, Münster U, Wagner D (2007) Methanogenic communities in permafrost-affected soils of the Laptev Sea coast, Siberian Arctic, characterized by $16 \mathrm{~S}$ rRNA gene fingerprints. FEMS Microbiol Ecol 59:476-488

20. Guindon S, Gascuel O (2003) A simple, fast, and accurate algorithm to estimate large phylogenies by maximum likelihood. Syst Biol 52:696-704

21. Hanson RS, Hanson TE (1996) Methanotrophic bacteria. Microbiol Rev 60(2):439-471

22. Henckel T, Frierich M, Conrad R (1999) Molecular analyses of the methane-oxidizing microbial community in rice field soil by targeting the genes of the $16 \mathrm{~S}$ rRNA, particulate methane monooxygenase, and methanol dehydrogenase. Appl Environ Microbiol 65:1980-1990

23. Henckel T, Jäckel U, Schnell S, Conrad R (2000) Molecular analysis of novel methanotrophic communities in forest soils that oxidize atmospheric methane. Appl Environ Microbiol 66:1801-1808

24. Henckel T, Jäckel U, Conrad R (2001) Vertical distribution of the methanotrophic community after drainage of rice field soil. FEMS Microbiol Ecol 34:279-291

25. Heyer J, Berger U, Hardt M, Dunfield PF (2005) Methylohalobius crimeensis gen. nov., sp. nov., a moderately halophilic, methanotrophic bacterium isolated from hypersaline lakes of Crimea. Int $\mathrm{J}$ Syst Evol Microbiol 55:1817-1826

26. Holmes AJ, Costello A, Lidstrom ME, Murrell JC (1995) Evidence that particulate methane monooxygenase and ammonia monooxygenase may be evolutionarily related. FEMS Microbiol Lett 132:203-208

27. Houghton JT, Ding Y, Griggs DJ, Noguer M, van der Linden PJ, Xiaosu D (eds) (2001) Climate Change 2001: the scientific basis. Contribution of Working Group I to the Third Assessment Report of the Intergovernmental Panel on Climate Change. Cambridge University Press, Cambridge, UK 944pp

28. Horz HP, Yimga MT, Liesack W (2001) Detection of methanotroph diversity on roots of submerged rice plants by molecular retrieval of pmoA, mmoX, mxaF, and $16 \mathrm{~S}$ rRNA and ribosomal DNA, including $p m o A$-based terminal restriction fragment length polymorphism profiling. Appl Environ Microbiol 67:4177-4185

29. Horz HP, Rich V, Avrahami S, Bohannan BJM (2005) Methaneoxidizing bacteria in a California upland grassland soil: diversity and response to stimulated global change. Appl Environ Microbiol 71:2642-2652

30. Huber T, Faulkner G, Hugenholtz P (2004) Bellerophon; a program to detect chimeric sequences in multiple sequence alignments. Bioinformatics 20:2317-2319

31. Kaluzhnaya MG, Makutina VA, Rusakova TG, Nikitin DV, Khmelenina VN, Dmitriev VV, Trotsenko YA (2002) Methanotrophic communities in the soils of the Russian northern taiga and subarctic tundra. Microbiology 71:223-227 (translated from Mikrobiologiya)

32. Khmelenina VN, Makutina VA, Kaluzhnaya MG, Rivkina EM, Gilichinsky DA, Trotsenko YA (2001) Discovery of viable methanotrophic bacteria in permafrost sediments of northeast Siberia. Dokl Biol Sci 384:235-237 (English translation)

33. Kolb S, Knief C, Dunfiled PF, Conrad R (2005) Abundance and activity of uncultured methanotrophic bacteria in the consumption of atmospheric methane in two forest soils. Environ Microbiol 7:1150-1161

34. Lane DJ (1991) 16S/23S rRNA sequencing. In: Stackebrandt E, Goodfellow M (eds) Nucleic acid techniques in bacterial systematics. Wiley, Chichester, UK, pp 115-175

35. Lau E, Ahmad A, Steudler PA, Cavanaugh CM (2007) Molecular characterization of methanotrophic communities in forest soils that consume atmospheric methane. FEMS Microbiol Ecol 60:490-500

36. Le Mer J, Roger P (2001) Production, oxidation, emission and consumption of methane by soils: a review. Eur J Soi Bio 37:25-50 
37. Liebner S, Wagner D (2007) Abundance, distribution and potential activity of methane oxidizing bacteria in permafrost soils from the Lena Delta, Siberia. Environ Microbiol 9:107-117

38. Macalady JL, McMillan AM, Dickens AF, Tyler SC, Scow KM (2002) Population dynamics of type I and II methanotrophic bacteria in rice soils. Environ Microbiol 4(3):148-157

39. McDonald IR Hall GH, Pickup RW, Murrell JC (1996) Methane oxidation potentials and preliminary analysis of methanotrophs in a blanket bog peat using molecular ecology techniques. FEMS Microbiol Ecol 21:197-211

40. McDonald IR, Murrell JC (1997) The particulate methane monooxygenase gene pmoA and its use as a functional gene probe for methanotrophs. FEMS Microbiol Lett 156:205-210

41. Omelchenko MB, Vasieleva LV, Zavarzin GA, Savelieva ND, Lysenko AM, Mityushina LL, Khmelenina VN, Trotsenko YA (1996) A novel psychrophilic methanotroph of the genus Methylobacter. Microbiology 65:339-343 (translated from Mikrobiologiya)

42. Pester M, Friedrich MW, Schink B, Brune A (2004) pmoA-based analysis of methanotrophs in a Littoral Lake sediment reveals a diverse and stable community in a dynamic environment. Appl Environ Microbiol 70:3138-3142

43. Radajewski S, Webster G, Reay DS, Morris SA, Ineson P, Nedwell DB, Prosser JI, Murrell CJ (2002) Identification of active methylotroph populations in an acidic forest soil by stableisotope probing. Microbiology 148:2331-2342

44. Rahalkar M, Schink B (2007) Comparison of aerobic methanotrophic communities in littoral and profundal sediments of Lake Constance by a molecular approach. Appl Environ Microbiol 73:4389-4394

45. Rahalkar M, Bussmann I, Schink B (2007) Methylosoma difficile gen. nov., sp. nov., a novel methanotroph enriched by gradient cultivation from littoral sediment of Lake Constance. Int J Syst Evol Microbiol 57:1073-1080

46. Ricke P, Kube M, Nakagawa S, Erkel C, Reinhardt R, Liesack W (2005) First genome data from uncultured upland soil cluster alpha methanotrophs provide further evidence for a close phylogenetic relationship to Methylocapsa acidophila B2 and for high-affinity methanotrophy involving particulate methane monooxygenase. Appl Environ Microbiol 71:7472-7482

47. Roslev P, King GM (1996) Regulation of methane oxidation in a freshwater wetland by water table changes and anoxia. FEMS Microbiol Ecol 19:105-115
48. Schloss PD, Handelsman J (2004) Status of the microbial census. Microbiol Mol Biol Rev 68:686-691

49. Schloss PD, Handelsman J (2005) Introducing DOTUR, a computer program for defining operational taxonomic units and estimating species richness. Appl Environ Microbiol 71:1501-1506

50. Schwamborn G, Rachold V, Grigoriev MN (2002) Late Quaternary sedimentation history of the Lena Delta. Quat Int 89:119-134

51. Seeberg-Elverfeldt J, Schlueter M, Feseker T, Köllig M (2005) Rhizon sampling of porewaters near the sediment-water interface of aquatic systems. Limnol Oceanogr Methods 3:361-371

52. Stoecker K, Bendinger B, Schöning B, Nielsen PH, Nielsen JL, Baranyi C, Toenshoff ER, Daims H, Wagner M (2006) Cohn's Crenothrix is a filamentous methaneoxidizer with an unusual methane monooxygenase. Proc Natl Acad Sci USA 14:2363-2367

53. Trotsenko YA, Khmelenina VN (2005) Aerobic methanotrophic bacteria of cold ecosystems. FEMS Microbio Ecol 53:15-26

54. Tsubota J, Eshinimaev BT, Khmelenina VN, Trotsenko YA (2005) Methylothermus thermalis gen. nov., sp. nov., a novel moderately thermophilic obligate methanotroph from a hot spring in Japan. Int J Syst Evol Microbiol 55:1877-1884

55. Wagner D, Lipski A, Embacher A, Gattinger A (2005) Methane fluxes in extreme permafrost habitats of the Lena Delta: effects of microbial community structure and organic matter quality. Environ Microbiol 7:1582-1592

56. Wagner D (2008) Microbial communities and processes in arctic permafrost environments. In: Dion P, Chandra SN (eds) Microbiology of extreme soils. Soil biology. vol. 13. Springer, Berlin, pp 133-154

57. Wartiainen I, Hestnes AG, Svenning MM (2003) Methanotrophic diversity in high arctic wetlands on the islands of Svalbard (Norway) - denaturing gradient gel electrophoresis analysis of soil DNA and enrichment cultures. Can J Microbiol 49:602-612

58. Wartiainen I, Hestnes AG, McDonald IR, Svenning MM (2006) Methylobacter tundripaludum sp. nov., a novel methanotrophic bacterium from Arctic wetland soil, Svalbard, Norway $\left(78^{\circ} \mathrm{N}\right)$. Int J Syst Evol Microbiol 56:109-113

59. Wise MG, McArthur JV, Shimkets LJ (1999) Methanotroph diversity in landfill soil: isolation of novel type I and type II methanotrophs whose presence was suggested by culture-independent $16 \mathrm{~S}$ ribosomal DNA analysis. Appl Environ Microbiol 65:4887-4897

60. Wise MG, McArthur JV, Shimkets LJ (2001) Methylosarcina fibrata gen. nov.. sp. nov. and Methylosarcina quisquiliarum sp. nov., novel type I methanotrophs. Int J Syst Evol Microbiol 51:611-621 